\title{
Probiyotikler ve Belirlenmelerinde Kullanılan in vitro Testler
}

\author{
Hafsa BİLGINER* ${ }^{*}$ Bülent ÇETIN \\ Atatürk Üniversitesi, Ziraat Fakültesi, Gıda Mühendisliği Bölümü, Erzurum, Türkiye \\ (*Sorumlu yazar e-mail: hafsabilginer@gmail.com) \\ DOI: 10.17097/ataunizfd.549552
}

\begin{abstract}
ÖZ: Fonksiyonel gıdalara ve sağlıklı beslenmeye olan ilginin her geçen gün artması ile birlikte probiyotikler, bilim dünyasının önemli çalıșma alanlarından biri haline gelmiștir. İnsan ve probiyotikler arasındaki mutual ilișkinin zamanla yeni boyutlar kazanması, konu üzerindeki çalışma sayısını ve probiyotik ürünlere olan ilgiyi daha da artırmaktadır. Probiyotik bir ürün üretmeden önce, o üründe kullanılacak mikroorganizmaların probiyotik olup olmadığının tespitinde ve güvenlik değerlendirmelerinde, in vitro ve in vivo testlerden faydalanılmaktadır. Bu derlemede, muhtemel probiyotik sușun insan gastrointestinal sistemiyle uyumuna yönelik olarak kullanılan; mide ortamına direnç, safra tuzuna tolerans, antibiyotik direnci, antagonistik etki, kolesterol asimilasyonu, bağırsak yüzeyine yapıșma ve model gastrointestinal sistemler hakkında özet bilgi verilmeye çalıșılmıștır.
\end{abstract}

Anahtar Kelimeler: Probiyotik, In vitro testler, Gastrointestinal sistem

\section{Probiotics and in vitro Tests Used for Their Determination}

\begin{abstract}
With the increasing attention to functional foods and healthy nutrition, probiotic microorganisms have become one of the most important fields of study in the scientific world. As the emergence of new dimensions of mutual positive relationship between human and probiotics, the number of studies on the subject and the attention to probiotic products have increased even more. Before producing a probiotic product, in vitro and in vivo tests are used to determine whether the microorganisms are probiotics. In this review, it has been tried to provide information about the probable probiotic strain used in the compliance with the human gastrointestinal tract; resistance to gastric environment, tolerance to bile salt, antibiotic resistance, cholesterol assimilation, intestinal surface adhesion and model gastrointestinal systems.
\end{abstract}

Keywords: Probiotics, In vitro tests, Gastrointestinal system

\section{GíRiş}

Son yillarda tüketicilerin daha da bilinçlenmesinin bir sonucu olarak, beslenme yoluyla sağlığın korunmasına olan eğilim artmıştır. Bu durum, fonksiyonel gida terimini ve sektörünü ortaya çıkarmıştır. Fonksiyonel gıdalar kısaca, "besinsel değerine ilave olarak sağlığı olumlu etkileyen gidalar" olarak tanımlanmaktadır. Günümüzde ise bu sektörün önemli bir kısmını probiyotik gıdalar oluşturmaktadır (Gülbandılar vd., 2017). 2007 yılında başlatılan mikrobiyom projesiyle, insan vücudunda yaşayan mikrofloranın sağlık üzerindeki önemli etkileri daha belirgin bir şekilde ortaya çıkmıştır. Bundan dolayı, probiyotiklerin önemi ve bu konuda yapilan çalışmaların sayısı artmıştır (Heiman and Greenway, 2016). Mevcut literatür incelendiğinde konu ile ilgili derleme ve araştırma makalelerinin bulunduğu görülmektedir. Ancak, probiyotik mikroorganizmaların tespitinde kullanılan metotların sunulduğu, ülkemiz kaynaklı bir yayına rastlanılmamıştır. Bu çalışmada, konu ile ilgili güncel bazı terimlere yer verilerek probiyotik mikroorganizmaların özelliklerinin kanıtlanmasında kullanılan metotlar açıklanmaya çalışılmıştır.

Probiyotik, prebiyotik, simbiyotik, posbiyotik ve psikobiyotik

Probiyotik terimi Yunanca kökenli olup “pro" ve "biotic" kelimelerinin birleşmesiyle oluşmuş, "yaşam için" anlamına gelen bir terimdir (Gupta and Garg, 2009). FAO ve WHO (2002) tarafindan ise, "Yeterli miktarda vücuda alındıklarında insan sağlığı üzerinde olumlu etkiler gösteren canlı mikroorganizmalar" şeklinde tanımlanmıştır. Bu terim ilk olarak, 1965 yılında Lilly ve Stilwell tarafindan kullanılmıştır (Soccol et al., 2010). Probiyotiklerın önemli bir kısmını laktik asit bakterileri (LAB) oluşturmakta ve bunlar arasında da Bifidobacterim ve Lactobacillus türleri en çok kullanılan laktik probiyotikler olarak yer almaktadır. Bununla beraber konu ile ilgili literatür incelendiğinde farklı kaynaklardan izole edilmiş ve probiyotik özellikleri kanıtlanmış farklı suşların varlığ 1 da görülmektedir. Bu suşların bugün itibariyle gıdalarda kullanımları olmasa da, gelecekte gida üretiminde veya tıbbi amaçlı çalışmalarda yer almaları muhtemeldir. Konu ile ilgili araştırmalar özellikle bakteriler üzerinde yoğunlaşmakla beraber maya ve küf türlerinin de probiyotik özelliklerinin araştırıldığ görülmektedir (Çizelge 1, Çizelge 2). Posbiyotik ise, probiyotiklerin ürettiği canlı olmayan bakteriyel veya metabolik yan ürünlere denilmektedir. Bakteriyosinler, organik asitler, hidrojen peroksit, enzimler, kısa zincirli yağ asitleri, ekzopolisakkaritler, polifosfat, düşük molekül ağırlıklı metabolitler gibi ürünler posbiyotiklere örnek verilebilir (Çetin, 2006; FAO, 2002; Uymaz, 2009; Kerry et al., 2018). 
Çizelge 1. Probiyotik olarak kullanılan mikroorganizmalar (Collins et al., 1998; WGO, 2008; Tannis, 2008; Uymaz, 2010; Erem vd., 2013; Kerry et al., 2018).

\begin{tabular}{|c|c|}
\hline Cins & Tür \\
\hline Akkermansia & Akkermansia mисiniphila \\
\hline Bacillus & $\begin{array}{l}\text { Bacillus cereus, Bacillus clausii, Bacillus coagulans, } \\
\text { Bacillus laterosporus, Bacillus lentus, Bacillus licheniformis, Bacillus } \\
\text { polyfermenticus, Bacillus pumilus, Bacillus subtilis }\end{array}$ \\
\hline Bacterioides & $\begin{array}{l}\text { Bacterioides amylophilus, Bacterioides capillus, } \\
\text { Bacterioides suis, Bacterioides uniformis } \\
\text { Bacterioides ruminicola, }\end{array}$ \\
\hline Bifidobacterium & $\begin{array}{l}\text { Bifidobacterium adolescentis, Bifidobacterium animalis } \\
\text { Bifidobacterium bifidum, Bifidobacterium breve, } \\
\text { Bifidobacterium catenulatum, Bifidobacterium infantis, Bifidobacterium lactis, } \\
\text { Bifidobacterium longum, Bifidobacterium thermophilum }\end{array}$ \\
\hline Enterococcus & Enterococcus faecalis, Enterococcus faecium \\
\hline Escherichia & Escherichia coli Nissle 1917 \\
\hline Lactobacillus & $\begin{array}{l}\text { Lactobacillus acidophilus, Lactobacillus brevis, } \\
\text { Lactobacillus bulgaricus, Lactobacillus casei, } \\
\text { Lactobacillus cellobiosus, Lactobacillus crispatus } \\
\text { Lactobacillus curvatus, Lactobacillus delbrueckii, Lactobacillus fermentum, } \\
\text { Lactobacillus helveticus, Lactobacillus gasseri, Lactobacillus jonhsonii, } \\
\text { Lactobacillus plantarum, Lactobacillus reuteri, } \\
\text { Lactobacillus rhamnosus, Lactobacillus salivarius }\end{array}$ \\
\hline Lactococcus & Lactococcus lactis ssp. Lactis \\
\hline Leuconostoc & Leuconostoc mesenteroides ssp. mesenteroides \\
\hline Pediococcus & $\begin{array}{l}\text { Pediococcus cerevisiae, Pediococcus acidilactici, } \\
\text { Pediococcus pentosaceus }\end{array}$ \\
\hline Peptostreptococcus & Peptostreptococcus productus \\
\hline Propionibacterium & $\begin{array}{l}\text { Propionibacterium jensenii, Propionibacterium shermanii, } \\
\text { Propionibacterium freudenreichii }\end{array}$ \\
\hline Streptococcus & $\begin{array}{l}\text { Streptococcus intermedius, Streptococcus sanguis } \\
\text { Streptococcus mitis, Streptococcus salivarius, } \\
\text { Streptococcus thermophilus, Streptococcus oralis }\end{array}$ \\
\hline Küfler & Aspergillus niger, Aspergillus oryzae \\
\hline Mayalar & $\begin{array}{l}\text { Saccharomyces cerevisiae, Saccharomyces boulardii, } \\
\text { Candida torulopsis }\end{array}$ \\
\hline
\end{tabular}

Probiyotik mikroorganizmanın tipi (tür, cins, suş), canlı veya ölü oluşu, ürettiği metabolitler, gıdada bulunduğu miktar ve yaşayabilirliği; konakçının genotipik özellikleri, bağırsak mikroflorası ve fizikokimyasal özellikleri probiyotiklerin yararlı etkilerini göstermede önemli faktörlerdir. Ayrıca suşun adaptasyonu ve probiyotik olma potansiyeli de önemli faktörler arasında yer almaktadır (Shenderov, 2011).

Probiyotikler çoğunlukla yoğurt, kefir, kımız, peynir gibi fermente süt ürünlerinde starter kültür olarak kullanılmaktadır. Probiyotik yoğurt ürünlerinin satış1 ilk olarak 1980'lerde Avrupa'da görülmüştür (Yiğit, 2009). Günümüzde dondurarak kurutma yöntemi ile tablet ve kapsül gibi farmasötik preparatlar şeklinde de piyasada yer almaktadırlar (Anonim, 2018). Buzdolabında muhafaza edilen probiyotik gıdaların raf ömrü 3-6 hafta arasında değişmektedir. $\mathrm{Bu}$ ürünler buzdolabında muhafaza edilmeyenlere göre daha stabildir. Kurutulmuş farmasötik preparatların raf ömrü 12 hafta olsa da, probiyotik mikroorganizma miktarı katılan bakteri düzeyine göre değişmekle birlikte, genellikle 12 ay içinde önemli oranda azalmaktadır (Hoolihan, 2001). Bakterilerin ürettiği hidrojen peroksit ve asit, ürünün oksijen içeriği, paketin oksijen geçirgenliği, sıcaklık, $\mathrm{pH}$ gibi pek çok etken de fermente ürünlerde kullanılan probiyotik bakterilerin canlılığı üzerine etki etmektedir. Ortamın olumsuz etkilerini azaltmak için probiyotiklerin çevresinde fiziksel bir bariyer yani mikroenkapsülasyon tekniği uygulanabilmekte ve böylece mikroorganizma olumsuz çevre şartlarından korunabilmektedir (Kıran ve Osmanağaoğlu, 2012; De Melo Pereira et al., 2018; Panghal et al., 2018). 
Çizelge 2. Probiyotik suşları içeren bazı ticari ürün örnekleri (WGO, 2008; Anonymous, 2018c)

\begin{tabular}{|c|c|c|c|}
\hline Suş & Marka adı & Üretici & Gida ürünü \\
\hline Bifidobacterium lactis DN 173010 & Activia & Danone/Dannon & Yoğurt \\
\hline Bifidobacterium breve Yakult & Bifiene & Yakult & $\begin{array}{l}\text { Probiyotik süt } \\
\text { içeceği }\end{array}$ \\
\hline Lactobacillus casei Shirota & Yakult & Yakult & $\begin{array}{l}\text { Probiyotik süt } \\
\text { içeceği }\end{array}$ \\
\hline EnterococcusLAB SF 68 & Bioflorin & Cerbios-Pharma & $\begin{array}{c}\text { Farmasötik } \\
\text { preparat }\end{array}$ \\
\hline Lactobacillus casei $\mathrm{F} 19$ & Cultura & Arla Foods & Yoğurt \\
\hline $\begin{array}{l}\text { Lactobacillus johnsonii La1, } \\
\text { Streptococcus thermophilus }\end{array}$ & LC1 & Nestlé & $\begin{array}{l}\text { Probiyotik süt } \\
\text { içeceği }\end{array}$ \\
\hline Lactobacillus plantarum $299 \mathrm{~V}$ & GoodBelly, ProViva & NextFoods Probi & $\begin{array}{l}\text { Probiyotik } \\
\text { meyve suyu } \\
\text { içeceği }\end{array}$ \\
\hline Lactococcus lactis L1A & Verum & Norrmejerier & $\begin{array}{l}\text { Probiyotik süt } \\
\text { içeceği }\end{array}$ \\
\hline Escherichia coli Nissle 1917 & Mutaflor & Ardeypharm & $\begin{array}{l}\text { Farmasötik } \\
\text { preparat }\end{array}$ \\
\hline Saccharomyces cerevisiae (boulardii) lyo & $\begin{array}{l}\text { DiarSafe, } \\
\text { Ultralevure ve } \\
\text { diğerleri }\end{array}$ & $\begin{array}{l}\text { Wren Laboratories, } \\
\text { Biocodex }\end{array}$ & $\begin{array}{c}\text { Farmasötik } \\
\text { preparat }\end{array}$ \\
\hline $\begin{array}{l}\text { Lactobacillus rhamnosus } \\
\text { Lactobacillus reuteri } \text { RC-14 }\end{array}$ & FemDophilus & Chr. Hansen & $\begin{array}{c}\text { Farmasötik } \\
\text { preparat }\end{array}$ \\
\hline 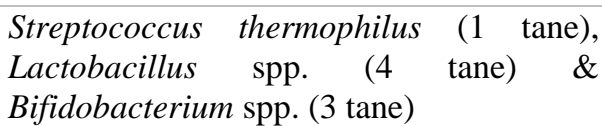 & VSL\#3 & $\begin{array}{l}\text { Sigma-Tau } \\
\text { Pharmaceuticals, Inc. }\end{array}$ & $\begin{array}{l}\text { Farmasötik } \\
\text { preparat }\end{array}$ \\
\hline Bacillus clausii suşları O/C, NR, SIN, ve T & Enterogermina & Sanofi-Aventis & $\begin{array}{c}\text { Farmasötik } \\
\text { preparat }\end{array}$ \\
\hline
\end{tabular}

Probiyotiklerin, vücutta etkili olabildikleri minumum konsantrasyon ile ilgili bilgiler hala yetersiz olmakla birlikte, genellikle bu bakterilerin probiyotik ürünlerde en az $10^{6}-10^{7} \mathrm{kob} / \mathrm{g}-\mathrm{ml}$ düzeyinde bulunması gerektiği ve probiyotik etki için günlük olarak yaklaşı $10^{6}-10^{9} \mathrm{kob} / \mathrm{g}$ düzeyinde probiyotik alınması gerektiği kabul edilmektedir (Zârate et al., 2000; Önal-Darılmaz, 2010; Erem vd., 2013; Anonim, 2006). Probiyotik suşların her şeyden önce toksin üretmeyen ve vücuda alındıklarında sağlığa zarar vermeyen, yani GRAS (Generally Regarded As Safe) statüsündeki mikroorganizmalardan seçilmiş olması gerekmektedir. Ayrıca, bir mikroorganizmanın probiyotik olarak gıdada kullanılabilmesi için; tercihen insan orijinli olması, patojen olmaması, mide asidine ve safra tuzuna dayanıklı olması, bağırsak yüzeyine tutunabilmesi, gastrointestinal sistemde kısa da olsa yaşamını devam ettirebilmesi, antimikrobiyal karakterde bileşikler üretebilmesi, antibiyotik direncinin olmaması, bağışıklık sistemini uyarması, metabolik etkiler gösterebilmesi, (kolesterol asimilasyonu, laktaz aktivitesi, vitamin üretimi) ve teknolojik süreçlere dayanıklı olması beklenmektedir (Collins et al., 1998; Dunne et al., 2001; ÖnalDarılmaz, 2010; Uymaz, 2010; Erem vd., 2013; Kechagia et al., 2013; Çomak-Göçer vd., 2016). Probiyotik suş seçiminde orijinin rolü sıklıkla tartışlan bir konudur. Farklı orijinlerden alınan probiyotik kültürlerin in vitro şartlardaki etkilerini gözlemlemek amacıyla yapılan bir araştırmada, insan orijinli Lactobacillus acidophilus DDS-1, hayvan orijinli Bifidobacterium animalis ssp. lactis UABla12, bitki orijinli Lactobacillus plantarum UALp-05 ve süt orijinli Streptococcus thermophilus UASt-09 suşları üzerinde çalışılmıştır. Elde edilen sonuçlara 
göre, tüm suşların simüle edilmiş sindirim sürecinde iyi bir canlı kalma oranı gösterdiği, intestinal epitelyuma güçlü bir şekilde yapıştığı ve yeterli bir immünomodülatör etki gösterdiği gözlenmiştir. Bununla birlikte, insan kaynaklı DDS-1 suşunun diğer suşlara kıyasla daha üstün özellikler göstermesinden dolay1 orijinin, probiyotik olma potansiyelini etkileyebileceği düşünülmüştür (Vemuri et al., 2018).

Konu ile ilgili sıkça karşılaşılan bir diğer terim ise "prebiyotik" terimidir. Prebiyotikler, sindirilmeden kalın bağırsağa geçen ve probiyotiklerin bağırsakta gelişimini ve aktivitesini teşvik eden ve böylece probiyotiklerin yararlı etkilerini artıran bileşiklerdir (Sezen, 2013; Kıray ve Kariptaş, 2015). Laktuloz, inülin, oligosakkaritler (maltoz, soya, ksiloz), oligofruktoz ve galaktoz içeren galaktooligosakkaritler (kurubaklagiller) prebiyotik besinsel kaynaklara örnek olarak verilebilir. (İnanç vd., 2005).

Probiyotiklerin ve prebiyotiklerin beraber kullanılması ile elde edilen ürünlere ise "simbiyotik" denir ve bu kelime sinerjizme dikkat çeker (Schrezenmeir and Vrese, 2001). Bu sayede, probiyotikler daha uzun süre yaşamlarını devam ettirebilir ve daha iyi kolonize olabilirler (Kıray ve Kariptaş, 2015).

Sıklıkla insan ve hayvan bağırsaklarından izole edilen ve probiyotik olarak seçilen mikroorganizmalar arasında Lactobacillus, Bifidobacterium ve Enterococcus cinsleri bulunmaktadır. Bununla birlikte, bağırsak yolunda normal olarak bulunmayan diğer bazı laktik asit üreten bakteriler de bazen probiyotik olarak kullanılmaktadır (Moreira et al., 2005).

Enterokoklar firsatçı patojenler olup enfeksiyonların yaygın bir nedeni olarak karşımıza çıkmaktadırlar. Ayrıca, bu bakteriler transfer edilebilir antibiyotik direnç genlerine sahiptirler. Bu durum, Enterokokların probiyotik olarak kullanımında bazı kaygılar oluştursa da, E. faecium ve E. faecalis gibi suşların bir kısmı güvenlik açısından araştırılmış ve bildirilen herhangi bir sorun olmaksızın 20 yıldan fazla süredir piyasada olduğu görülmüştür (Collins et al., 1998; Salminen et al., 2003; Franz et al., 2011).

Her probiyotik bakteri türü kendine has karakteristik özelliklere sahiptir. Bir probiyotik türünün diğerinden daha yararlı olduğu söylenemez. Her birinin farklı şekilde etkileri ve faydaları vardır. Belli bir rahatsızlığı olan kişi için hangi probiyotik bakterinin uygun olduğu, bakterinin vücutta nerelerde gelişebildiği ve kişinin yaşı ile alakalıdır. Örneğin, ince bağırsak Lactobasillerin gelişimi için, kolon ise Bifidobakterlerin gelişimi için daha uygundur. Bazı hastalık koşullarında, araştırmacılar hangi spesifik türün uygun olduğunu bilseler de konu ile ilgili çalışmaların artırılması gerekmektedir. Bununla birlikte, bağırsak yolunda çeşitli probiyotik türlerin karışımının kullanılması ile sinerjist etki sağlanarak daha olumlu sonuçlar alınmaktadır. Ayrıca yaşlılarda, hücre reseptörlerinde veya çevresel faktörlerde bir değişiklik olması, kolonlarında Bifidobakterlerin varlığının azalmasına neden olabilir. Çocukların probiyotik takviyelerinde, sağlıklı bir bebeğin bağırsağında yaşadığı bilinen Lactobacillus rhamnosus ve Bifidobacterium infantis gibi türlere odaklanılır (Tannis, 2008).

Son zamanlarda merak uyandıran bir başka terim ise psikobiyotiktir. Bu terim, ilk defa Dinan et al. (2013) tarafindan kullanılmıştır. Psikobiyotikler, yeterli miktarda tüketildikleri zaman kommensal bağırsak bakterileri ile etkileşimler yapma yoluyla zihinsel sağlık yararları sağlayan, bakteri-beyin ilişkilerini olumlu etkileyen, farklı moleküllerin oluşumunda rol alan probiyotik mikroorganizmalardır. Psikobiyotikler; $\gamma$ aminobutirik asit (GABA), norepinefrin, dopamin, serotonin ve asetilkolin gibi sinir sisteminde bulunan birçok nörotransmitter ve nöromodülatör maddeleri üretirler. Bu bakterilerin beyin fonksiyonlarını ve ruh halini olumlu yönde etkileme, depresyon ve anksiyeteyi tedavi etme ve stresle başa çıkma gibi mental yönde pek çok faydaları bulunmaktadır (Sarkar et al., 2016).

FAO/WHO (2002)'ya göre, bir bakterinin probiyotik olarak kabul edilip gidalarda kullanılabilmesi için gerekli olan basamaklar Şekil 1 'de verilmiştir.

Bir mikroorganizmanın, probiyotik olup olmadığ bazı metotlar kullanılarak tanılama işlemi gerçekleştirilmelidir. Fenotipik testlerin hem güvenilir olmaması hem de fazla zaman almasindan dolayı, son zamanlarda, fenotipik testlerin yerine geçebilen, daha hızlı ve güvenilir olan DNA/RNA bazlı genotipik tanı metodları kullanılmaktadır. Bunlar; klasik PCR, ERIC-PCR, REP-PCR, RAPD-PCR, RFLP, DGGE, TTGE, PFGE, 16S rRNA dizi analizi ve Real timePCR gibi PCR temelli yöntemlerdir (Trcek et al., 1997; Gonzalez et al., 2004;2005;2006; Gullo et al., 2006; De Vero and Giudici, 2008; Ilabaca et al., 2008; Jara et al., 2008; Papalexandratou et al., 2009; Perez et al., 2010; Vegas et al., 2013; Çetin vd., 2017; Bilginer, 2018). Tanılama işleminden sonra, suşun mide ortamına direnci, safra tuzuna tolerans1, antibiyotik direnci, kolesterol asimilasyonu, bağırsak yüzeyine yapışma gibi özellikleri belirlenerek probiyotik olma potansiyeli tespit edilmelidir. Probiyotik olma potansiyeli tespit edilen suşun, insanlar ve hayvanlar üzerindeki etkilerini belirlemek amacıyla in vivo testler yapılmalıdır. Testleri geçen suşlardan probiyotik bir ürün üretilecek ise, ürünün etiketi ile ilgili olarak Şekil 1'de belirtilen hususlara dikkat edilmelidir (FAO, 2002). Ülkemizde ise konu ile ilgili yasal düzenlemelere 25/08/2002 tarihli ve 
24857 say1lı, 07/07/2006 tarihli ve 26221 say1lı Resmî Gazetelerde yayınlanan ilgili tebliğlerde yer verilmiş olup, konunun Tarım ve Köyişleri Bakanlığ1 kontrolünde yürütülmesi öngörülmüştür. Ülkemizde bir ürünün probiyotik veya prebiyotik olarak etiketlenebilmesi için ilgili tebliğde yer alan "Gıda Bileşenleri İle İlgili Sağlık Beyan Tablosu (EK-9)" ndaki "Sağlık Beyanı" ve "Beyan Koşulu" gereksinimlerini sağlaması gerekmektedir (Anonim, 2002; 2006).

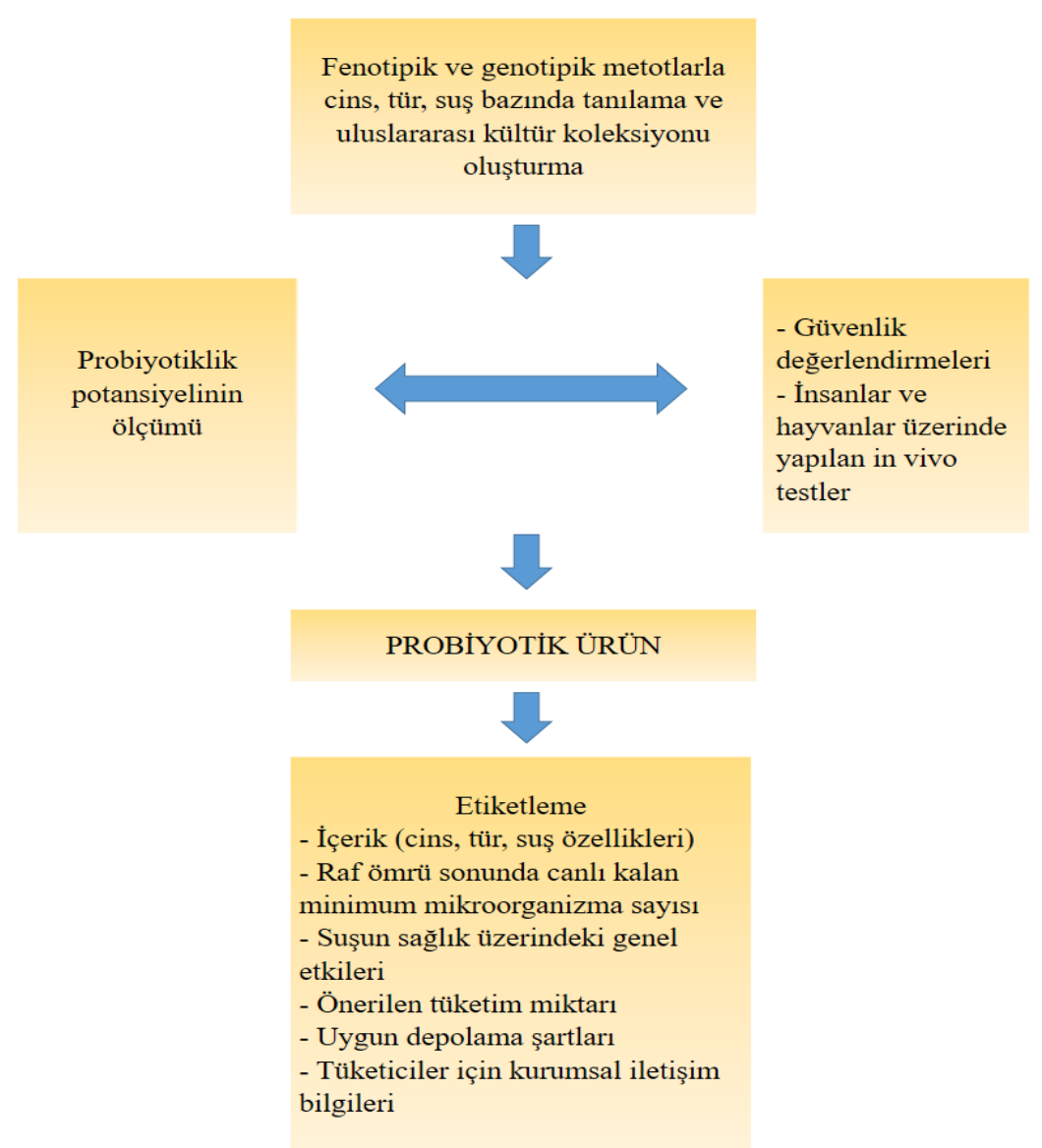

Şekil 1. Probiyotik ürün geliştirmek için takip edilecek genel basamaklar (FAO, 2002)

\section{Probiyotiklerin etki mekanizmaları}

Probiyotikler, bağırsak yüzeylerine tutunup kendilerine ekolojik bir yaşam alanı oluşturarak besin maddelerini kullanır ve böylece rekabet ortamı oluşturarak patojenlerin gelişimlerini sınırlandırırlar. Ayrıca, asetik asit ile laktik asit gibi çeşitli organik asitler üretip pH'yı düşürerek ve belirli koşullar altında hidrojen peroksit ile bakteriyosinler üreterek de diğer bakterilerin gelişmesini engellerler. Probiyotiklerin olumlu etkisi yalnızca gastrointestinal yolla sınırlı olmayıp, çeşitli besleyici ve terapötik etkiler sağladıkları da bilinmektedir. $\mathrm{Bu}$ bakterilerin katılımıla birlikte meydana gelen enzimatik hidroliz ile lipidlerin ve proteinlerin biyolojik olarak kullanılabilirliklerini artırmakta ve gida maddelerinin alerjenikliğini düşürmektedirler. Örneğin, laktozu sindirebilmekte ve fermente süt ürünlerinde laktoz seviyesini düşürerek laktoz intoleransı semptomlarını azaltmaktadirlar. Bunlara ilaveten, probiyotikler serum kolesterol seviyesini düşürmede, diyarenin tedavisinde ve engellenmesinde, Helicobacter pylori enfeksiyonunun ve enflamatuar barsak hastalığının kontrolünde etkili olup, çeşitli antikarsinojenik ve antimutajenik etkiler de göstermektedirler. Elde edilen bulgulara göre, probiyotiklerin yaraların iyileşme sürecinde olumlu etkileri olduğu, bebeklerde yapılan deneylerde probiyotik kullanımının ishali, kolik ağrısını, alerjik hastalıkları ve solunum ile ilgili rahatsızlıları azalttığı ve bağışıklık sistemini güçlendirdiği bildirilmektedir (Tomasik and Tomasik, 2003; Shah, 2004; Tannis, 2008; Hemaiswary, 2013; Tsiouris and Tsiouri, 2017). Probiyotiklerin etki mekanizmaları Şekil 2'de görülmektedir. 


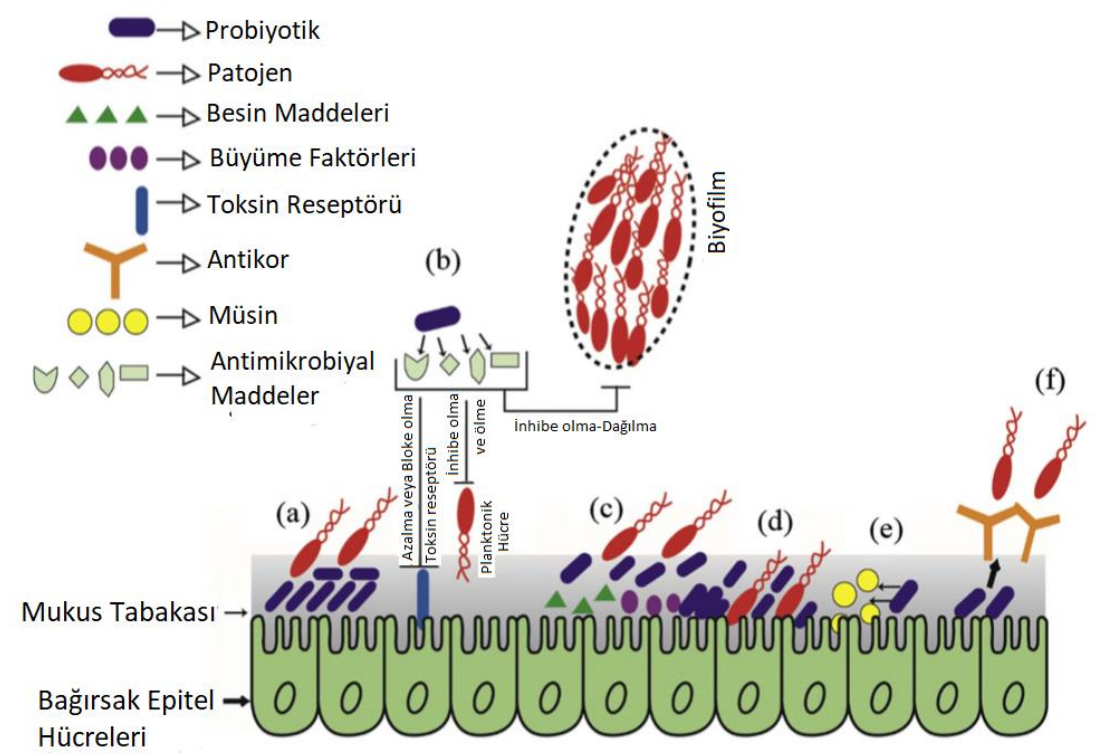

Şekil 2. Probiyotiklerin etki mekanizmaları (a) Patojen mikroorganizmalarla rekabet ederek yüzeye tutunum, (b) Antimikrobiyal maddelerin üretimi, (c) Besin maddeleri ve büyüme faktörleri için rekabet, (d) İntestinal epitel hücreye tutunumun artması, (e) Epitel bariyer fonksiyonunun artması, (f) İmmün sistemin uyarılması (Ig A üretiminin artmas1) /Figure 2. Mechanisms of action the probiotics (a) Adherance to surface by compete with pathogenic microorganisms, (b) Production of antimicrobial agents, (c) Competition for nutrients and growth factors, (d) Increased adherence to intestinal epithelial cell, (e) Increased epithelial barrier function, (f) Stimulation of the immune system (increased Ig A production) (Hossain et al. 2017'den modifiye edilmiştir)

\section{Probiyotik sușların belirlenmesinde kullanılan in vitro testler}

Bir mikroorganizmanın probiyotik olup olmadığını anlamak için in vitro ve in vivo testlerin yapılması gerekmektedir. Bunlar; mide ortamına direnç, safra tuzuna tolerans, antibiyotik direnci, kolesterol asimilasyonu, bağırsak yüzeyine yapışma testlerinden oluşmaktadır (Walker and Gilliland, 1993; Tuomola et al., 2001; FAO, 2002; Hummel et al., 2007).

\section{Mide ortamına direnç}

Probiyotiklerin asidik ortama dirençlerinin belirlenmesindeki amaç, midenin $\mathrm{pH}$ değerinin 2,0 civarında olması ve bu mikroorganizmaların bağırsak yoluna ulaşmadan önce, mideden geçerken canlı kalıp kalmadıklarının tespit edilmesidir. Yapılan çalışmalarda $\mathrm{pH}$ değeri 2,0 olan şartlar bazen çok seçici bir ortam sağlarken $\mathrm{pH}$ değeri 3,0 olan şartlarda farklı bakterilerin gelişim gösterebildiği gözlenmiştir. $\mathrm{Bu}$ nedenle $\mathrm{pH}$ değeri 2,5 olan şartlar daha uygun ortam olarak belirlenmiş ve kültürlerin bu pH'daki 0 ., 2. ve 4. saatlerdeki canlılıkları takip edilmiştir (Dunne et al., 2001; Özden, 2004; Yavuzdurmaz, 2007; Akman, 2009).

Asidik ortama direnç incelenirken temelde yapılmak istenen, muhtemel probiyotik mikroorganizmanın mideyi geçebilme yeteneğinin ortaya koyulmasıdır. Bu özellik incelenirken, mide
pH'sındaki solüsyonlarda mikroorganizmalar inkübe edilmekte ve belli sürelerin sonunda canlı kalan mikroorganizma sayısı ilgili besiyerlerine ekim yapılarak tespit edilebilmektedir. Ayrıca, mide simülasyon çözeltileri de günümüzde bu amaçla kullanılmaktadır. Sindirim modellerinde en çok sindirim enzimleri (pankreatin, pepsin, tripsin, kimotripsin, peptidaz, amilaz, lipaz), safra tuzu ve müsin kullanılmaktadır. Farklı tip ve konsantrasyonda enzim kullanılmasına rağmen, sindirim modellerinin hepsinde işlem sıcaklığ $37^{\circ} \mathrm{C}$ 'ye ayarlanmaktadır. Sindirim süresi olarak mide, ince bağırsak ve kalın bağırsak bölümlerinin her biri için çoğunlukla ikişer saat kullanılmaktadır (Dunne et al., 2001; Argyri et al., 2013; Elcioglu and Kunduhoglu, 2014; Çomak-Göçer vd., 2016).

\section{Safra tuzuna tolerans}

Sindirim sisteminde antimikrobiyal etkili mekanizmalardan bir tanesi de safra tuzlarıdır. Safra asidi, karaciğerde kolesterolden sentezlenir ve safra kesesinden konjuge formda on iki parmak bağırsağına gönderilir. Bu asitler, çoğunlukla mikrobiyal aktivite sonucunda kolonda kimyasal modifikasyonlara (dekonjügasyon, dehidroksilasyon, dehidrojenasyon ve deglukuronidasyon) uğramakta, bakterilerin büyük oranda lipit ve yağ asidi içeren hücre membranlarına zarar vererek inhibitör etkisi yapmaktadırlar. Hem konjuje hem de dekonjuge safra asitleri Escherichia 
coli suşları, Klebsiella spp. ve Enterococcus spp. üzerinde inhibe edici etkiye sahiptir. Ayrica, dekonjuge formlarının daha fazla inhibe edici etkiye sahip olduğu ve gram pozitif bakterilerin gram negatif bakterilere göre daha hassas olduğu da bildirilmiştir. Mikroorganizmaları etkileyen bu özelliğinden dolayı, muhtemel probiyotik suşların bağırsaklarda fonksiyon gösterebilmeleri için safraya karşı dirençli olmaları gerekmektedir. Laboratuvar ortamında probiyotik adayı mikroorganizmaların safra tuzlarına toleransı incelenirken genellikle ilgili besiyerindeki \%0,3, \%0,5 ve $\% 1$ konsantrasyonlu ortamlarda gelişimi belli saat aralıklarla (0., 2. ve 4. saat) takip edilmektedir (Prasad et al., 1998; Dunne et al., 2001; Akman, 2009; ÖnalDarilmaz, 2010; Zago, 2011; Elcioglu and Kunduhoglu, 2014). Dunne et al. (2001), sığır ve domuz safrası üzerinde yaptıkları bir çalışmada, deneyde kullandıkları Lactobacillus ve Bifidobacterium suşlarının, sığır safrasına direnç gösterirken domuz safrasına direnç göstermediklerini tespit etmişlerdir.

Gastrointestinal sistemden geçerken mikroorganizmaların canlı kalıp kalmadığının tespiti için, çeşitli in vivo ve in vitro çalışmalar yapılmaktadır. Ancak insan sindirim sisteminden geçişi sırasında mikroorganizmaların canlılığını etkileyen faktörlerin saptanması ile ilgili in vivo çalışmalar oldukça zordur. Konu ile ilgili yapılan in vitro çalışmaların nispeten kolay, hızlı, güvenilir olması ve özellikle in vivo çalışmalarda karşılaşılan etik kısıtlamalar nedeniyle günümüzde mide ve safra simülasyon çözeltilerinin kullanımı yaygındır. Ayrıca, son yıllarda sindirim sisteminin tümünü ifade eden simülasyon düzenekleri de kullanılmaktadır. $\mathrm{Bu}$ sistemlerin en gelişmişlerinde, ağızdan başlayarak kalın bağırsağa kadar tüm aşamalar sindirim sistemiyle benzeştirilmektedir (Çomak-Göçer vd., 2016; TNO, 2017).

\section{Antimikrobiyal maddelerin üretimi}

Laktik asit bakterileri tarafından üretilen çeşitli metabolik bileşiklerin (organik asitler, yă asitleri, hidrojen peroksit ve diasetil dahil) antimikrobiyal etkileri vardır. Bununla birlikte, bakteriyosin üreterek yakın ilişkili suşlar üzerinde antibiyotik etki gösteren laktik asit bakterileri mevcuttur. Bunlar içerisinde nisin gıdalarda geniş kullanım alanı olan bir bakteriyosindir. Çizelge 3'de laktik asit bakterileri tarafindan üretilen antimikrobiyel maddeler ve etki spektrumları görülmektedir (Fuller, 1992; Dunne et al., 2001; Kurt ve Zorba, 2005; Chikindas et al., 2018). Dunne et al. (2001), insan bağırsağından izole ettikleri Laktobasiller ve Bifidobakterlerin Listeria, Bacillus, Enterococcus, Staphylococcus, Clostridium, Pseudomonas, E. coli, Streptococcus, Lactobacillus, Lactococcus ve Bifidobacterium üzerinde antimikrobiyal etki gösterip göstermediğini test etmek istemişlerdir. Elde ettikleri sonuçlara göre; $L$. salivarius UCC118 suşunun Lactobasiller (Lactobacillus fermentum hariç) ve Bifidobakterleri etkilemediği, diğer bakterilere karşı antagonistik etki gösterdiği belirlenmiştir.

Çizelge 3. Laktik asit bakterileri tarafından üretilen antimikrobiyel maddeler ve etki spektrumları (Fuller, 1992; Çetin, 2006)

\begin{tabular}{|l|l|}
\hline \multicolumn{1}{|l|}{ Metabolik ürün } & \multicolumn{1}{c|}{ Etki spektrumu } \\
\hline Organik asitler & Putrefaktif ve Gram (-) bakteriler, bazı küfler \\
\hline -Laktik asit & Putrefaktif bakteriler, Clostridium'lar, bazı maya ve küfler \\
\hline -Asetik asit & Patojenler ve bozulma etkeni mikroorganizmalar \\
\hline Hidrojen peroksit & \\
\hline Enzimler & Patojenler ve bozulma etkeni bakteriler (Süt ve süt Ürünleri) \\
\hline -Laktoperoksidaz sistemi $\left(\mathrm{H}_{2} \mathrm{O}_{2}\right.$ 'li) & İstenmeyen Gram(+) bakteriler \\
\hline -Lizozim (rDNA tekn. ile üretilen) & \\
\hline Düşük molekül ağırlıklı metabolitler & Geniş bakteri spektrumu, maya ve küfler \\
\hline -Reuterin (3-OH-propionaldehit) & Gram (-) bakteriler \\
\hline -Diasetil & Çeşitli bakteriler \\
\hline -Yağ asitleri & \\
\hline Bakteriosinler & Bazı LAB ve Gram(+) bakteriler, bazı sporlu bakteriler \\
\hline $\begin{array}{l}\text {-Nisin, Asidolin, Asidofilin, Laktasin B, } \\
\text { Bulgarisin, Lactosin 27, Helvetisin J, } \\
\text { Pediosin AcH, Plantarisin B, Plantarisin } \\
\text { A, Plantarisin SIK 83, Reuterin, Sakasin } \\
\text { A, Laktosin S }\end{array}$ & \\
\hline
\end{tabular}

Bir mikroorganizmanın antagonistik etkisinin belirlenmesi amacıyla genellikle disk difüzyon (DD), kuyu difüzyon (KD) ve minimal inhibisyon konsantrasyonu (MIK) testleri yapılmaktadır. DD testinde bakteri süpernatantı bir diske emdirilmekte ve hedef mikroorganizmanın bulunduğu ortama 
konulmaktadır. Disk çevresinde görülen berrak zon ve çapı antagonistik etki hakkında bilgi vermektedir. KD metodunda ise agarda oluşturulan kuyucuklar, antibiyotik özelliği incelenmek istenen sıv1 ile doldurulmakta, inkübasyon sonrası antimikrobiyal etki sonucu oluşan berrak zon ve çapı ölçülmektedir. MÍK testinde, etken maddenin etki ettiği en düşük doz belirlenmektedir. $\mathrm{Bu}$ amaçla, hazırlanan farklı konsantrasyonlarda araştırılmak istenen çözelti hedef mikroorganizma üzerinde denenmekte ve inhibisyonun görüldüğü konsantrasyon MIKK değeri olarak kabul edilmektedir (Hummel et al., 2007; Anonymous, 2018a; De Melo Pereira et al., 2018).

\section{Antibiyotik direnci}

Laktik asit bakterileri farklı yapıdaki antibiyotik maddelere (penisilin, tetrasiklin, vankomisin, gentamisin, kloramfenikol vb.) karşı duyarlı veya dirençli yapıda olabilmektedirler (Gad et al., 2014). Bu durum, probiyotikler açısından ilk bakışta olumlu bir karakter olarak görünse de istenen bir özellik değildir. Çünkü antibiyotik direnci mikroorganizmalar arasında aktarılabilir bir karakterdir. Avrupa'da sadece fermente süt ürünlerinin kişi başına tüketimi $22 \mathrm{~kg}$ olduğu düşünüldüğünde, toplamda yıllık 8,5 milyar $\mathrm{kg}$ ürün tüketilmektedir. Bitkisel ve hayvansal fermente gıdalarla beraber bu rakamlar daha da artmaktadır. Dolayısıyla, starter ve probiyotik kültürleri içeren laktik asit bakterileri gıdalarımızda ve çevremizde oldukça yüksek sayılarda bulunmaktadır. Bundan dolayı gıdalarda kullanılan kültürler, antibiyotik direnç genlerinin muhtemel taşıyıcısı olarak görülmektedir (Hummel et al., 2007; Meral ve Korukluoğlu, 2014).

Gıdalarda kullanılacak mikroorganizmaların antibiyotik genlerini içermesi istenmediğinden, organizmanın antibiyotik direnci açısından test edilmesi gerekmektedir. Mikroorganizmanın antibiyotik direnci genel olarak klasik ve moleküler testlerle yapılmaktadır. Klasik olarak; disk difüzyon testi (DD), minimal inhibisyon konsantrasyonu (MİK) testi ve otomatik antimikrobiyal hassasiyet testi uygulanmaktadır. Moleküler temelli testlerde ise ilgili genin PCR metotları kullanılarak taraması gerçekleştirilmektedir (Hummel et al., 2007; Anonymous, 2018a; De Melo Pereira et al., 2018). Çizelge 4'de bazı bakterilere ait EFSA (European Food Safety Authority)'nın bildirdiği antimikrobiyal duyarlılık değerleri görülmektedir.

Çizelge 4. Bazı bakteriyal inhibisyon değerleri (mg/L) (EFSA, 2012)

\begin{tabular}{|c|c|c|c|c|c|c|c|c|c|}
\hline & 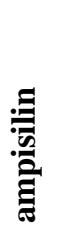 & 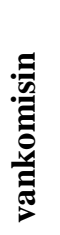 & 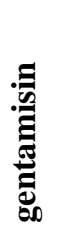 & 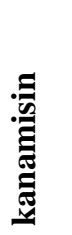 & 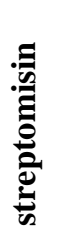 & & 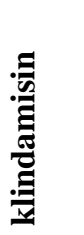 & 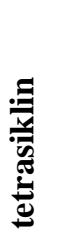 & 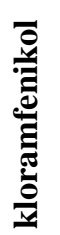 \\
\hline Lactobacillus reuteri & 2 & - & 8 & 64 & 64 & 1 & 1 & 16 & 4 \\
\hline $\begin{array}{l}\text { Lactobacillus } \\
\text { plantarum/pentosus }\end{array}$ & 2 & - & 16 & 64 & - & 1 & 2 & 32 & 8 \\
\hline Lactobacillus rhamnosus & 4 & - & 16 & 64 & 32 & 1 & 1 & 8 & 4 \\
\hline $\begin{array}{l}\text { Lactobacillus casei } \\
\text { /paracasei }\end{array}$ & 4 & - & 32 & 64 & 64 & 1 & 1 & 4 & 4 \\
\hline Lactococcus lactis & 2 & 4 & 32 & 64 & 32 & 1 & 1 & 4 & 8 \\
\hline Bifidobacterium & 2 & 2 & 64 & - & 128 & 8 & 1 & 1 & 4 \\
\hline Pediococcus & 4 & - & 16 & 64 & 64 & 1 & 1 & 8 & 4 \\
\hline Leuconostoc & 2 & - & 16 & 16 & 64 & 1 & 1 & 8 & 4 \\
\hline Propionibacterium & 2 & 4 & 64 & 64 & 64 & 0.5 & 0.25 & 2 & 2 \\
\hline
\end{tabular}

: inhibisyon değeri önerilmemiş

\section{Kolesterol asimilasyonu}

Kolesterol canlılar için önemli bir molekül olup, özellikle hücre membranında rol almaktadır. İnsan beslenmesinde ihtiyaç duyulan kolesterolün bir kısmı vücut tarafından üretilirken diğer kısmı gıdalarla alınmaktadır. Ancak, aşırı alındığında kan kolesterol seviyesi yükselmekte ve istenmeyen sağlik sorunlarına neden olmaktadır. Bu nedenle, bağırsak 
florası tarafından kolesterol miktarının redükte edilmesi, istenilen bir özellik olmuş ve probiyotikler kolesterol seviyelerini düşürdükleri için ilgi gören mikroorganizmalar olmuşlardır (Walker and Gilliland, 1993).

Bazı probiyotik suşların kolesterolü asimile ettikleri ve probiyotik laktik asit bakterilerin $\mathrm{pH}$ değerini düşürmeleri sonucunda dekonjuge safra tuzlarının ve kolesterolün presipitasyonuna neden oldukları şeklinde hipotezler mevcuttur. En çok kabul gören hipotez ise, probiyotik Laktobasiller ile Bifidobakterlerin safra tuzlarını safra tuzu hidrolaz enzimi (BSH) ile serbest asitlere parçalayıp konjuge safra tuzlarını intestinal sistemden daha hızlı uzaklaştırdıkları ve böylece kolesterol konsantrasyonunu düşürdükleri yönündedir. Farklı çalışmalarda, bazı bakterilerin membran yapısına katılarak ya da kolesterol yüzeyine tutunarak, kolesterolün bağırsaklardan kana emilimini azaltabildiği belirlenmiştir (Alp ve Ertürkmen, 2017).

Muhtemel probiyotiklerin kolesterol asimilasyon testi mikroorganizmaların bu özelliğini tespit etmek amacıyla yapılmaktadır. Bu denemelerde, genel olarak bilinen miktarda kolesterol içeren besiyerlerinde probiyotik adayı mikroorganizma inkübe edilmekte, inkübasyon sonunda ortamdaki kolesterol miktarı ölçülerek başlangıç seviyesine göre fark belirlenmektedir (Walker and Gilliland, 1993). Tsai et al. (2013), probiyotiklerin in vitro ortamdaki BSH aktivitesini ve kolesterol dekonjuge etme yeteneklerini belirlemek için yüksek performanslı sıvı kromatografisini (HPLC) kullanmışlardır. CastorenaAlba et al. (2017), kolesterol asimilasyon yüzdesini görmek amaciyla kolesterol içeren safra ve asit ortamı (MRS besiyeri ile) hazırlamışlar, bu ortama taze kültürlerin ekimini yaptıktan sonra $37^{\circ} \mathrm{C}$ 'de 12 saatlik inkübasyona bırakmışlardır. İnkübasyon süresi boyunca her bir saatte spektrofotometrede $(650 \mathrm{~nm})$ ölçüm yaparak kolesterol miktarını tayin etmişlerdir. $\mathrm{Bu}$ amaçla inkübasyondan sonra $3000 \mathrm{x}$ g'de 10 dakika $\left(4^{\circ} \mathrm{C}\right)$ santrifüj işleminin ardından üstte kalan sıvıyı ayırıp dipte kalan peleti kurutmuşlardır. Kuru peleti, çıkarılan sıvıya eşit hacimde steril su ile sulandırarak çözmüşler ve absorbans ölçümünü gerçekleştirerek pelette kalan kolesterol miktarını AlSaleh et al. (2006)'in belirttiği formüle göre hesaplamışlardır. Çalışma sonucunda kolesterol asimilasyon kabiliyetinin suşa bağlı olduğu ve \% 0100 arasında değiştiği belirtilmiştir.

\section{Bağırsak yüzeyine tutunma}

Mide asidine ve safra tuzlarına karşı direnç gösterip ince bağırsağa ulaşan probiyotikler ilk olarak mukus tabakası ile temas ederler. Probiyotiklerin peristaltik hareketlerle ince bağırsaktan kayıp gitmemesi için, bağırsak lümenini örten mukus tabakasına ve epitel hücrelerine tutunması gerekmektedir. Bu tutunmayla, patojenlerin bağırsak yüzeyine tutunumunun engellenmesi, probiyotiklerin sindirim sisteminde kalma sürelerinin nispeten uzaması, immün sistemin aktive edilmesi ve zarar görmüş bağırsak epitelinin daha kolay iyileşmesi sağlanmaktadır (Önal vd., 2005; Çomak-Göçer, 2016).

Mikroorganizmaların epitel hücrelere yapışması, hücre yüzeyinin hem agregasyon (kümeleşme) kapasitesi hem de hidrofobik özellikleri ile ilişkilidir. Probiyotiklerin konakçıda yararlı etkiler gösterebilmesi için agregasyon özellikleri ile yeterli yoğunlukta olmaları gerekmektedir. Bakterilerin agregasyon özelliğine sahip olmaları, hücreye tutunum ve baskın şekilde kolonize olmalarını sağlayacağı için probiyotiklik açısından önemli bir kriterdir. Agregasyon, otoagregasyon ve koagregasyon olmak üzere iki şekilde gerçekleşmektedir. Aynı türe ait mikroorganizmaların birbirlerine tutunarak oluşturdukları hücre kolonileri otoagregasyon, farklı türe ait mikroorganizmaların birbirine tutunarak oluşturdukları hücre kolonileri ise koagregasyon olarak tanımlanmaktadır. Probiyotikler otoagregasyon yetenekleri ile bağırsak epitel hücrelerine tutunabilmekte, koagregasyon yetenekleriyle de patojenlerin kolonizasyonunu önlemektedirler (Önal-Darılmaz, 2010). Bu amaçla kültürler; 5000 x g'de 15 dakika $\left(4^{\circ} \mathrm{C}\right)$ santrifüj edilmekte ve elde edilen pelet PBS (Fosfat buffer salin-pH 7.2) ile $2 \mathrm{kez}$ yıkanmakta ve aynı tamponda $600 \mathrm{~nm}$ 'de ilk ölçüm gerçekleştirilmektedir. $37^{\circ} \mathrm{C}$ 'de 4 saatlik inkübasyondan sonra $600 \mathrm{~nm}$ 'de tekrar ölçüm yapılıp, 0 . ve 4 . saatlerdeki değerler otoagregasyon formülünde yerine konularak otoagregasyon yüzdeleri hesaplanmaktadır. Koagregasyonda ise probiyotik kültür, patojen kültür ve probiyotik-patojen içeren karışık kültür için ayrı ayrı yukarıda belirtilen işlemler gerçekleştirilerek koagregasyon formülünde yerine konulmakta ve koagregasyon yüzdeleri hesaplanmaktadır (Önal-Darılmaz, 2010; Balakrishna, 2013; Escamilla-Montes et al., 2015; Prabhurajeswar and Chandrakanth, 2018). Epitel yüzeye tutunmada agregasyon ile beraber hidrofobisitenin de gerekli olduğu, ancak agregasyon ile hidrofobisite arasında doğrudan bir ilişki olmadığı bildirilmiştir. Tutunma olayında konak hücre yüzeyinin hidrofob oluşu, yüzey yükleri ile ilişkilidir. Bakteri ve konak hücre yüzeyleri negatif (-) yüke sahip oldukları için bu itici güç özel etkileşimlerle aşılmaktadır (Önal-Darılmaz, 2010).

Hücre yüzeyi hidrofobikliği testinde ksilen, kloroform, etil asetat, hekzadekan gibi hidrokarbonlara tutunum yüzdesinin belirlenmesi amacıyla, taze kültürler $5000 \mathrm{x}$ g'de 15 dakika $\left(4^{\circ} \mathrm{C}\right)$ santrifüj edilmekte ve elde edilen pelet PBS (Fosfat buffer salin-pH 7.2) ile 2 kez yıkanmakta ve aynı tamponda 600 nm'de ilk ölçüm gerçekleştirilmektedir. Bakteri süspansiyonundan $1 \mathrm{ml}$ alınarak, ksilen, 
kloroform, etil asetat ve hekzadekan hidrokarbonlarının üzerine konulmakta ve oda sicaklığında $10 \mathrm{dk}$ bekletilmektedir. $10 \mathrm{dk}$ 'lık inkübasyondan sonra ayrılan iki faz 2 dakika vorteks ile karıştırılmakta ve tekrar oda sicaklığında 4 saat inkübe edilmektedir. İnkübasyondan sonra sulu fazın optik yoğunluğu spektrofotometrede $(600 \mathrm{~nm})$ ölçülmekte, değerler hidrofobisite formülünde yerine konularak hidrofobisitenin yüzdesel olarak hesab1 yapılmaktadır (Önal-Darılmaz, 2010; Abdulla et al., 2014; De Melo Pereira et al., 2018).

Bakteriler mideden geçip bağırsağa ulaştıkları zaman probiyotik özelliklerini gösterebilmelerindeki en büyük avantajlardan biri de ekzopolisakkarit (EPS) üretim kapasitelerine sahip olmalarıdır. EPS üretimi, mide ve bağırsak koşullarının olumsuz etkilerinden korunma ve bağırsakta kolonizasyonu artırma gibi probiyotik suşa çeşitli faydalar sağlamaktadır. ÖnalDarılmaz (2010), EPS üretimi yüksek propionibakteri suşlarının asitliğe ve safraya daha dirençli olduklarını, bununla beraber epitel hücrelere tutunmanın belirleyicisi olan oto ve koagregasyon kapasitelerinin daha yüksek olduğunu tespit etmiştir.

Probiyotiklerin intestinal sistemle olan etkileşimlerini anlayabilmek için kullanılacak veriler in vivo testlerle de elde edilebilir. Ancak bu çalışmaların diğer faktörlerden bağımsız ve rahatlıkla yapılabilmesi oldukça zordur. Bu amaçla, kolon hücre hatlarının kullanıldığı hücre kültürü çalışmaları, mikrobiyal adhezyon özelliğini değerlendirmenin bir başka yoludur. Hücre kültürü, hücrelerin normal fizyolojisi ve biyokimyasını, ilaçların ve toksik bileşiklerin hücreler üzerindeki etkilerini incelemek için model sistemler sağlayan başlıca araçlardan biridir. Bağırsak yüzeyine tutunmaya yönelik araştırmalarda, normal insan ince bağırsak villus hücrelerinin özelliklerine sahip olan Caco-2, HT-29, LS174T ve fetal I-407 hücre hatları, hücre kültürü çalışmalarında yaygın olarak kullanılmaktadır. Bununla birlikte adhezyonun incelenmesi dışında hücrelerin probiyotiklere gösterdiği reaksiyonu incelemek için de hücre kültürü kullanılmaktadır (Blum et al., 1999; Dunne et al., 2001; Brito et al., 2012; Argyri et al., 2013; Anonymous, 2018b; De Melo Pereira et al., 2018; Vemuri et al., 2018).

Probiyotik özelliklerin değerlendirilme işlemleri tamamlandıktan sonra, ilgili suşlar in vivo testlere tabi tutulmaktadir (De Melo Pereira et al., 2018). Probiyotiklerle ilgili olarak fare, sıçan ve domuzlarda in vivo testlerin yapıldığ çeşitli çalışmalar mevcuttur (Sarkar et al., 2016; Kim et al., 2018; Walcher et al., 2018). Ancak, çoğu kez artan maliyet ve etik nedenlerden dolayı in vivo testler yapılamamaktadır. $\mathrm{Bu}$ amaçla, in vitro testlerle daha standart veriler elde edebilmek için, bu konuda daha fazla çalışma yapılmalı ve deney protokollerinin iyileştirilmesi gerekmektedir (Papadimitriou et al., 2015).
$\mathrm{Bu}$ testlerden farklı olarak genom, transkriptom, proteom ve metabolom profilleme gibi son teknolojik gelişmeler; asit ve safra tuzu direnci, adhezyon kapasitesi, antimikrobiyal madde salgılanması gibi metabolik aktiviteyle ilişkili olan genlerin, farklı koşullar altında ekspresyonunu değerlendirerek probiyotiklerin doğru seçilmesi için öngörü modellerinin geliştirilmesini sağlamıştır. Ancak gen ifadesinin çevresel koşullara bağlı olduğu düşünüldüğünde, doğru probiyotik seçiminin in vitro ve in vivo çalışmalarla doğrulanması gerekmektedir (De Melo Pereira et al., 2018).

\section{SONUC}

Bir mikroorganizmanın probiyotik olarak gıdada kullanılabilmesi için; tercihen insan orijinli olması, patojen olmaması, mide asidine ve safra tuzuna dayanıklı olması, bağırsak yüzeyine tutunabilmesi, gastrointestinal sistemde kısa da olsa yaşamını devam ettirebilmesi, antimikrobiyal karakterde bileşikler üretebilmesi, bağışıklık sistemini uyarması, metabolik etkiler gösterebilmesi, (kolesterol asimilasyonu, laktaz aktivitesi vb.) ve teknolojik süreçlere dayanıklı olması beklenmektedir. $\mathrm{Bu}$ nedenle probiyotik suşların seçiminde mide ortamına direnç, safra tuzuna tolerans, antibiyotik direnci, antagonistik aktivite, kolesterol asimilasyonu, bağırsak yüzeyine yapışma ve in vivo testlere başvurulmaktadır. Bu derleme ile FAO/WHO'nun belirttiği standartlara uygun probiyotik bir suşun seçimi için bahsedilen testlere ilişkin detaylar verilmiştir.

\section{KAYNAKLAR}

Abdulla, A.A., Abed, T.A., Saeed, A.M., 2014. Adhesion, Autoaggregation and Hydrophobicity of Six Lactobacillus Strains. Br. Microbiol. Res. J., 4 (4): 381-391.

Akman, E., 2009. Bazı Laktik Asit Bakterilerinin Probiyotik Özelliklerinin İncelenmesi. Yüksek Lisans Tezi, İstanbul Teknik Üniv. Fen Bilimleri Enstitüsü, İstanbul.

Al Saleh, A.A., Metwalli, A.A.M., Abu-Tarboush, H.M., 2006. Bile Salts and Acid Tolerance and Cholesterol Removal from Media by some Lactic Acid Bacteria and Bifidobacteria. Saudi Society Food Nutr., 1 (1): 1-17.

Alp D., Ertürkmen P., 2017. Probiyotik Olarak Kullanılan Lactobacillus spp. Suşlarının Kolesterol Düşürücü Etkileri ve Olası Mekanizmalar. Mehmet Akif Ersoy Üniv. Fen Bilimleri Enstitüsü Derg., 8 (1): 108-113.

Anonim, 2002. Türk Gıda Kodeksi Gıda Maddelerinin Genel Etiketleme ve Beslenme Yönünden Etiketleme Kuralları Tebliği (No: 2002/58). Resmi Gazete, 24857: 25/08/2002, http://www.resmigazete.gov.tr/eskiler/2002/08/ 
20020825.htm\#7 (Erişim Tarihi: 2 Ağustos 2019).

Anonim, 2006. Türk Gıda Kodeksi Gıda Maddelerinin Genel Etiketleme ve Beslenme Yönünden Etiketleme Kuralları Tebliğinde Değişiklik Yapılması Hakkında Tebliğ, Tebliğ No (2006/34). Resmi Gazete, 26221: 07/07/2006, http://www.resmigazete.gov.tr/eskiler/2006/07/ 20060707-14.htm (Erişim Tarihi: 2 Ağustos 2019).

Anonim, 2018. Probiyotik Tablet, Kapsül, Toz ve Sıv1 Çeşitleri ve Suplementansiklopedisi.com, https:// supplementansiklopedisi.com/probiyotiktabletkapsultoz-sivi-cesitleri-farklari/ (Erişim Tarihi: 11 Şubat 2018).

Anonymous, 2018a. Examples of Antibiotic Sensitivity Testing Methods. Antimicrobial Resistance Learning Site, https://amrls.cvm.msu.edu/microbiology/detecti ng-antimicrobial-resistance/test-

methods/examples-of-antibiotic-sensitivitytesing-methods (Erişim Tarihi: 14 Şubat 2018).

Anonymous, 2018b. Introduction to Cell Culture. Thermo Fisher Scientific, https:// www.thermofisher.com / tr / en / home / references / gibco-cell-culture-basics/ introduction-to-cell-culture.html (Erişim Tarihi: 23 Aralık 2018).

Anonymous, 2018c. What is LCS. Yakult, https://www.yakult.co.in/yakult-LCS.php (Erişim Tarihi: 13 Şubat 2018).

Argyri, A.A., Zoumpopoulou, G., Karatzas, K.A.G., Tsakalidou E., Nychas G.J.E., Panagou E.Z., Tassou C.C., 2013. Selection of Potential Probiotic Lactic Acid Bacteria from Fermented Olives by İn Vitro Tests. Food Micro., 33: 282291.

Balakrishna, A., 2013. In vitro Evaluation of Adhesion and Aggregation Abilities of Four Potential Probiotic Strains Isolated from Guppy (Poecilia reticulata). Braz. Arch. Biol. Technol., 56 (5): 793-800.

Bilginer, H., 2018. Geleneksel Yöntemlerle Üretilen Sirkelerin Bazı Mikrobiyolojik Özelliklerinin Belirlenmesi, Mikrobiyotasında Yer Alan Asetik Asit Bakterilerinin İzolasyonu ve Moleküler Yöntemlerle Tanısı. Yüksek Lisans Tezi, Atatürk Üniv. Gıda Mühendisliği Anabilim Dalı, Erzurum.

Blum, S., Reniero, R., Schiffrin E.J., Crittenden, R., Mattila-Sandholm, T., Ouwehand, A.C., Salminen, S., Wright, A., Saarela, M., Saxelin, M., Collins, K., Morelli,L., 1999. Adhesion Studies for Probiotics: Need for Validation and Refinement. Trends in Food Sci. Tech., 10: 405410.
Brito, M.B., Diaz, J.P., Quzada, S.M., Llorente, C.G., Gil, A., 2012. Probiotic Mechanisms of Action. Ann. Nutr. Metab., 61: 160-174.

Chikindas, M.L., Weeks, R., Drider, D., Chistyakov, V.A., Dicks, L.M., 2018. Functions and Emerging Applications of Bacteriocins. Curr. Opin. Biotechnol., 49: 23-28.

Collins, J.K., Thornton, G., Sullivan, G.O., 1998. Selection of Probiotic Strains for Human Applications. Int. Dairy J., 8: 487-490.

Costorena-Alba, M.M., Vázquez-Rodríguez, J.A., Lomeli, M.L.C., González-Martínez B.E., 2017. Cholesterol Assimilation, Acid and Bile Survival Of Probiotic Bacteria İsolated from Food and Reference Strains. CYTA-J. Food, 16(1): 36-41.

Çetin, B., 2006. Koruyucu Kültür ve Laktik Asit Uygulamalarının Tavuk Etinde Raf Ömrü ve Salmonella Typhimurium Gelişimi ve Önemli Bazı Mikroorganizmaların İnhibisyonu Üzerine Etkileri. Doktora Tezi, Atatürk Üniv. G1da Mühendisliği Anabilim Dalı, Erzurum.

Çetin, B., Çakmakçı, S., Yıldız, H., Bilginer, H., Tarakçıŏglu, F., 2017. Turşu Fermantasyonunda Kullanılabilecek Laktik Asit Bakterilerinin Belirlenmesi ve Probiyotik Turşu Üretimi için Uygun Suşların Seçimi, Proje Sonuç Raporu. Tübitak, Ankara.

Çomak-Göçer E.M.Ç., Ergin F., Küçükçetin A., 2016. Sindirim Sistemi Modellerinde Probiyotik Mikroorganizmaların Canlılığı. Akademik Gıda, 14 (2): 158-165.

De Melo Pereira, G.V., Coelho, B.D.O., Junior, A.I.M., Thomaz-Soccol, V., Soccol, C.R., 2018. How to select a probiotic? A review and update of methods and criteria. Biotech. Adv. J., 07349750.

De Vero, L., Giudici, P., 2008. Genus-Specific Profile of Acetic Acid Bacteria by $16 \mathrm{~S}$ rDNA PCRDGGE. Int. J. Microbiol, Food, 125: 96-101.

Dinan T.G., Stanton C., Cryan J.F., 2013. Psychobiotics: A Novel Class of Psychotropic. Biol. Psychiatry, 74 (10): 720-726.

Dunne, C., O’Mahony, L., Murphy, L., Thornton, G., Morrissey, D., O'Halloran, S., Feeney, M., Flynn, S., Fitzgerald, G., Daly, C., Kiely, B., O’Sullivan, G.C., Shanahan, F., Collins, J.K., 2001. In Vitro Selection Criteria for Probiotic Bacteria of Human Origin: Correlation with İn Vivo Findings. Am. J. Clin. Nutr., 73: 386S-92S.

Elcioglu, O., Kunduhoglu, B., 2014. Probiotic Characteristics of Natural Lactobacilli Isolated from Traditional Karg1 Tulum Cheese. Ital. J. Food Sci., 26: 31-41.

Erem, F., Küçükçetin, A., Certel, M., 2013. Bacillus Türlerinin Probiyotik Olarak Değerlendirilmesi. Gida, 38 (4): 247-254. 
Escamilla-Monte,s R., Luna-Gonzále, A., FloresMiranda, M.D.C., Álvarez-Ruiz, P., FierroCoronado, J.A., Sánchez-Ortiz, A.C., ÁvilaLeal, J., 2015. Isolation and Characterization of Potential Probiotic Bacteria Suitable for Mollusk Larvae Cultures. Thai J. Vet. Med., 45 (1): 1121.

European Food Safety Authority (EFSA), 2012. Guidance on the Assessment of Bacterial Susceptibility to Antimicrobials of Human and Veterinary Importance. Parma, Italy.

FAO, 2002. Guidelines for the Evaluation of Probiotics in Food. World Health OrganizationFood and Agriculture Organization of The United Nations, London, Ontario, Canada.

Franz, C.M.A.P., Huch, M., Abriouel, H., Holzapfel, W., Galvez, A., 2011. Enterococci As Probiotics and Their İmplications in Food Safety. Int. Microbiol Food., 151: 125-140.

Fuller R., 1992. Probiotics, The Scientific Basis. Springer Science-Business Media Dordrecht, Edinburgh, Scotland.

Gad, G.F.M., Abdel-Hamid, A.M., Farag Z.S.H., 2014. Antibiotic Resistance in Lactic Acid Bacteria İsolated from Some Pharmaceutical and Dairy Products. Braz. J. Microbiol., 45 (1): 2533.

Gonzalez, A., Guillamon, J.M., Mas, A., Poblet, M., 2006. Application of Molecular Methods for Routine Identification of Acetic Acid Bacteria. Int. Microbiol Food., 108: 141-146.

Gonzalez, A., Hierro, N., Poblet, M., Mas, A., Guillamon, J.M., 2005. Enumeration and Detection of Acetic Acid Bacteria by Real-Time PCR and Nested PCR. FEMS Microbiol., 254: 123-128.

Gonzalez, A., Hierro, N., Poblet, M., Rozes, N., Mas A., Guillamon, J.M., 2004. Application of Molecular Methods for the Differentiation of Acetic Acid Bacteria in A Red Wine Fermentation. J. Appl. Microbiol., 96: 853-860.

Gullo, M., Caggia, C., De Vero, L., Giudici, P., 2006. Characterization of Acetic Acid Bacteria in Traditional Balsamic Vinegar. Int. J. Food Microbiol., 106: 209-212.

Gupta, V., Garg, R., 2009. Probiotics. Indian J. Med. Microbiol., 27(3): 202-9.

Gülbandilar, A., Okur M., Dönmez M., 2017. Fonksiyonel Gida Olarak Kullanılan Probiyotikler ve Özellikleri. Türk Bilimsel Derlemeler Derg., 10 (1): 44-47.

Heiman, M. L., Greenway, F. L., 2016. A Healthy Gastrointestinal Microbiome is Dependent on Dietary Diversity. J. Mol. Med., 5: 317-320.

Hemaiswary, S., Raja, R., Ravikumar, R., Carvalho, I.S., 2013. Mechanism of Action of Probiotics. Braz. Arch. Biol. Technol., 56 (1): 113-119.
Hoolihan, L.K., 2001. Prophylactic and Therapeutic Uses of Probiotics: A Review. J. Am. Diet. Assoc., 101 (2): 229-241.

Hossain, M.I., Sadekuzzaman, M., Ha, S.D., 2017. Probiotics As Potential Alternative Biocontrol Agents in The Agriculture And Food Industries: A Review. Food Res. Int., 100: 63-73.

Hummel, A.S., Hertel, C., Holzapfel, W.H., Franz, C.M.A.P., 2007. Antibiotic Resistances of Starter and Probiotic Strains of Lactic Acid Bacteria. Appl. Environ. Microbiol., 730-739.

Ilabaca, C., Navarrete, P., Mardones, P., Romero, J., Mas, A., 2008. Application of Culture CultureIndepent Molecular Biology Based Methods to Evaluate Acetic Acid Bacteria Diversity During Vinegar Processing. Int. J. Food Microbiol., 126: 245-249.

İnanç, N., Şahin, H., Çiçek, B., 2005. Probiyotik ve Prebiyotiklerin Sağlık Üzerine Etkileri. Erciyes Tip Derg. (Erciyes Med. J.), 27(3): 122-127.

Jara C., Mateo E., Guillamon J.M., Torija M.J., Mas A., 2008. Analysis Several of Methods for the Extraction of High Quality DNA From Acetic Acid Bacteria in Wine and Vinegar for Characterization by PCR-Based Methods. Int. J. Food Microbiol., 128: 336-341.

Kechagia, M., Basoulis, D., Konstantopoulou, S., Dimitriadi, D., Gyftopoulou, K., Skarmoutsou, N., Fakiri, E.M., 2013. Health Benefits of Probiotics: A Review. ISRN Nutr., 481651: 1-7.

Kerry, R.G., Patra, J.K., Gouda, S., Park, Y., Shin, H.S., Das, G., 2018. Benefaction of Probiotics for Human Health: A Review. J. Food Drug Anal., 26 (3): 927-939.

Kıran, F. ve Osmanağaoğlu, Ö., 2012. Laktik Asit Bakterilerinin Probiyotik Olarak Kullanımı. Selçuk Üniv., Selçuk Tarım ve Gıda Bilimleri Derg., 26 (4): 60-67.

Kıray, E. ve Kariptaş, E., 2015. Probiyotikler, Prebiyotikler ve Sinbiyotiklerin Kolorektal Kanser İlişkisi. Elektronik Mikrobiyoloji Derg., TR, 13 (1): 28-46.

Kim, J., Kim, J., Kim, Y., Oh, S., Song, M., Choe, J.H., Whang,K.Y., Kim, K.H., Oh, S., 2018. Influences of Quorum-Quenching Probiotic Bacteria on The Gut Microbial Community and İmmune Function in Weaning Pigs. Anim. Sci. J., 89 (2): 412-422.

Kurt, Ş., Zorba, Ö., 2005. Bakteriyosinler ve Gıdalarda Kullanım Olanakları. Yüzüncü Y1l Üniv. Veteriner Fak. Derg., 16 (1): 77-83.

Meral, H., Korukluoğlu, M., 2014. Laktik Asit Bakterilerinin Antibiyotik Direnç Mekanizmaları. Uludağ Üniv. Ziraat Fak. Derg., 28 (2): 71-82.

Moreira, J.L.S., Mota, R.M., Horta, M.F., Teixeira, S.M., Neumann, E., Nicoli, J.R., Nunes A.C., 
2005. Identification to The Species Level of Lactobacillus İsolated in Probiotic Prospecting Studies of Human, Animal or Food Origin by 16S-23S rRNA Restriction Profiling. BMC Microbiol., 5: 15.

Önal, D., Beyatlı, Y., Aslım, B., 2005. Probiyotik Bakterilerin Epitel Yüzeylere Yapışması. Orlab On-Line Mikrobiyoloji Derg., 3 (9): 1-10.

Önal-Darılmaz, D., 2010. Geleneksel Türk Peynirlerinde Propiyonik Asit Bakteri Türlerinin Belirlenmesi ve Bazı Probiyotik Özelliklerinin Araştırılması. Doktora Tezi, Biyoloji, Gazi Üniv. Fen Bilimleri Enstitüsü, Ankara.

Özden, A., 2004. Mikrop ve Mide Hastalıkları. Türk Gastroenteroloji Vakfi, Fersa Matbaacılık, Ankara.

Panghal, A., Janghu, S., Virkar, K., Gat, Y., Kumar, V., Chhikara, N., 2018. Potential Non-Dairy Probiotic Products - A Healthy Approach. Food Biosci., 21: 80-89.

Papadimitriou, K., Zoumpopoulou, G., Foligne, B., Alexandraki, V., Kazou, M., Pot, B., Tsakalidou, E., Discovering Probiotic Microorganisms: In Vitro, In Vivo, Genetic And Omics Approaches. Front Microbiol., 6: 1-28.

Papalexandratou, Z., Cleenwerck, I., Vos, P., Vuyst, L., 2009. (GTG)5-PCR Reference Framework for Acetic Acid Bacteria. FEMS Microbiol., 301: 44-49.

Perez, R.F, Torres, C., Sanz, S., Larrea, F.R., 2010. Strain Typing of Bacteria Responsible for Vinegar Production by the Submerged Elaboration Method. Food Microbiol., 27: 973978.

Prabhurajeswar, C., Chandrakanth, K., 2018. Evaluation of Antimicrobial Properties and Their Substances Against Pathogenic Bacteria in-vitro by Probiotic Lactobacilli Strains İsolated from Commercial Yoghurt. Clin. Nutr. Exp., 1-19.

Prasad, J., Gill, H., Smart, J., Gopal, P.K., 1998. Selection and Characterisation of Lactobacillus and Bifidobacterium Strains for Use as Probiotics. Int. Dairy J., 8: 993-1002.

Salminen, S., Isolauri, E., Wright, A., 2003. Safety of Probiotic Bacteria. Reviews in Food and Nutrition Toxicity, Ed: V.R. Preedy, Taylor and Francis Group, New York, USA, 271-283.

Sarkar, A., Lehto, S.M., Harty, S., Dinan, T.G., Cryan, J.F., Burnet, P.F.J., 2016. Psychobiotics and the Manipulation of Bacteria-Gut-Brain Signals. Trends Neurosci., 39 (11): 763-781.

Schrezenmeir, J., Vrese, M., 2001. Probiotics, Prebiotics and Synbiotics-Approaching a Definition. Am. J. Clin. Nutr.., 73: 361S-4S.

Sezen, A.G., 2013. Prebiyotik, Probiyotik ve Sinbiyotiklerin İnsan ve Hayvan Sağlığı Üzerine
Etkileri. Atatürk Üniv. Veterinerlik Bilimleri Derg., 8 (3): 248-258.

Shah, N.P., 2004. Probiotics and Prebiotics. Agro Food Ind. Hi Tech, January/February.

Shenderov, B.A., 2011. Probiotic (Symbiotic) Bacterial Languages. Anaerobe, 17(6): 490-495.

Soccol, C.R., Vandenberghe, L.P.S., Spier, M.R., Medeiros, A.B.P., Yamagushi, C.T., Lindner, J.D., Pandey, A., Thomaz-Soccol, V., 2010. The Potential of Probiotics: A Review. Food Technol. Biotechnol., 48(4): 413-434.

Tannis, A., 2008. How You Can Use Probiotics to Fight Cholesterol, Cancer, Suberbugs, Digestive Complaints and More. HarperCollins Publishers Ltd., Toronto, Ontario, Canada.

TNO, 2017. TIM Gastrointestinal Systems. Netherlands, https://www.tno.nl /media/4057/tim_gastrointestinal_systems.pdf (Erişim Tarihi: 30 Ocak 2018).

Tomasik, P.J., Tomasik, P., 2003. Probiotics and Prebiotics. Am. Assoc. Cereal Che. Int. (AACCI), 80(2): 113-117.

Trcek, J., Ramus, J., Raspor, P., 1997. Phenotypic Characterization and RAPD-PCR Profilling of Acetobacter sp. Isolated from Spirit Vinegar Production. Food Technol. and Biotechnol., 5: 63-67.

Tsai, C.C., Lin, P., Hsieh, Y.M., Zhang, Z.Y., Wu, H.C., Huang, C.C., 2014. Cholesterol-Lowering Potentials of Lactic Acid Bacteria Based on BileSalt Hydrolase Activity and Effect of Potent Strains on Cholesterol Metabolism In Vitro and In Vivo. Sci. World J., 1-10.

Tsiouris, C.G., Tsiouri, M.G., 2017. Human Microflora, Probiotics and Wound Healing. Wound Med. J., 19: 33-38.

Tuomola, E., Crittenden, R., Playne, M., Isolauri, E., Salminen, S., 2001. Quality Assurance Criteria for Probiotic Bacteria. Am. J. Clin. Nutr., 73: 393S-8S.

Uymaz, B., 2010. Probiyotikler ve Kullanım Alanları. Pamukkale Üniv. Mühendislik Bilimleri Derg., 16 (1): 95-104.

Vegas, C., Gonzalez, A., Mateo, E., Mas, A., Poblet, M., Torija, M.J., 2013. Evaluation of Representativity of The Acetic Acid Bacteria Species Identified by Culture-Dependent Method During A Traditional Wine Vinegar Production. Food Res. Int., 51: 404-411.

Vemuri, R., Shinde, T., Shastri, M.D., Perera, A.P., Tristram, S., Martoni, C.J., Gundamaraju, R., Ahuja, K.D.K., Ball, M., Eri, R., 2018. A Human Origin Strain Lactobacillus Acidophilus DDS-1 Exhibits Superior in vitro Probiotic Efficacy in Comparison to Plant or Dairy Origin Probiotics. Int. J. Med. Sci., 15(9): 840-848. 
Walcher, D.L., Cruz, L.A.Z., De Lima Telmo, P., Martins, L.H.R., Da Costa De Avila, L.F., Berne, M.E.A., Scaini C.J., 2018. Lactobacillus rhamnosus Reduces Parasite Load on Toxocara Canis Experimental Infection in Mice, But Has No Effect on The Parasite In Vitro. Parasitol. Res., 117 (2): 597-602.

Walker, D.K., Gilliland, S.E., 1993. Relationships Among Bile Tolerance, Bile Salt Deconjugation, and Assimilation of Cholesterol by Lactobacillus acidophilus. J. Dairy Sci., 76 (4): 956-961.

WGO, 2008. Probiotics and Prebiotics. World Gastroenterology Organisation Practice Guideline, Milwaukee, USA.

Yavuzdurmaz, H., 2007. Isolation, Characterization, Determination Of Probiotic Properties of Lactic Acid Bacteria from Human Milk. MS Thesis, IZTECH, İzmir, Türkiye.
Yiğit, T., 2009. Süt ve Süt Ürünlerinden Probiyotik Bakterilerinin İzolasyonu ve Tanımlanması. Yüksek Lisans Tezi, Anadolu Üniv. Fen Bilimleri Enstitüsü, Eskişehir.

Zago, M., Fornasari, M.E., Carminati, D., Burns, P., Suàrez, V., Vinderola, G., Reinheimer, J., Giraffa G., 2011. Characterization and Probiotic Potential of Lactobacillus plantarum Strains İsolated from Cheeses. Food Microbiol., 28: 1033-1040.

Zárate, G., Pèrez-Chaia, A., González, S., Oliver, G., 2000. Viability and $\beta$-Galactosidase Activity of Dairy Propionibacteria Subjected to Digestion by Artificial Gastric and İntestinal Fluids. J. Food Protect., 63 (9): 1214-1221. 